\title{
Oznaczenie i indywidualizacja remitenta
}

Postanowienie Sądu Najwyższego z dnia 9 kwietnia 2018 r., I CSK 716/17

Zarówno ze wskazanych orzeczeń, jak i z pozostałego dorobku judykatury Sądu Najwyższego nie sposób wywieść konstatacji tak daleko idącej, jak poglądy skarżącego, obstającego przy stanowisku, że wszelkie skracanie rdzenia firmy - nawet jednoznaczne, używane powszechnie w obrocie i lepiej rozpoznawalne na rynku jest niedozwolone w obrocie prawnym (wekslowym). Przeciwnie, w orzecznictwie panuje stanowisko, że osoba prawna powinna być dostatecznie zindywidualizowana, a posługiwanie się nazwami handlowymi upowszechnionymi w obrocie masowym - dopuszczalne.

\section{Tomasz Tomczak}

Uniwersytet Opolski

tomasz.tomczak@uni.opole.pl

ORCID: 0000-0002-8499-4553

https://doi.org/10.26881/gsp.2021.3.13

\section{Glosa}

Dnia 9 kwietnia 2018 r. w sprawie I CSK 716/17', Sąd Najwyższy wydał postanowienie, w którym odmówił przyjęcia skargi kasacyjnej do rozpoznania. Takie rozstrzygnięcie może sugerować, że żaden komentarz do orzeczenia nie jest potrzebny, gdyż SN nie rozpoznawał sprawy merytorycznie. Jednak jedna z postawionych przez SN tez odnośnie kwestii oznaczenia na wekslu remitenta może budzić pewne wątpliwości, dlatego można poddać ją krytycznej analizie oraz szerzej zastanowić się nad oznaczeniem i indywidualizacją remitenta.

W stanie faktycznym omawianej sprawy pozwany złożył skargę kasacyjną od wyroku Sądu Apelacyjnego w Warszawie ${ }^{2}$, oddalającego apelację pozwanego od wyroku Sądu Okręgowego w Warszawie ${ }^{3}$, wydanego w sprawie o zapłatę.

\footnotetext{
Postanowienie z dnia 9 kwietnia 2018 r., I CSK 716/17, LEX nr 2508139.

Wyrok SA w Warszawie z dnia 31 stycznia 2017 r., I ACa 2148/15, LEX nr 2519439.

3 Wyrok SO w Warszawie z dnia 15 czerwca 2015 r., XXIV C 845/14, niepubl.
} 
Z treści wyroków wynika, że powód był bankiem i na zabezpieczenie udzielonego przez siebie kredytu uzyskał od pozwanego m.in. weksel własny in blanco. Bank, oznaczając siebie na wekslu jako remitenta, skrócił nie tylko swoją formę prawną, ale co istotne, korpus swojej firmy. Ów skrót występował w statucie banku, ale nie został wpisany do Krajowego Rejestru Sądowego. Na wekslu remitent nie był też oznaczony w inny, dodatkowy sposób (np. za pomocą numeru KRS).

Fragment postanowienia, który należałoby poddać krytycznej analizie brzmi w sposób następujący: „Zarówno ze wskazanych orzeczeń [wyroku SN z dnia 9 maja 2012 r., V CSK 258/11, OSNC 2013/1, poz. 9 oraz uchwała SN z dnia 10 października 2013 r., III CZP 54/13, OSNC 2014/6, poz. 56 - przyp. T.T.], jak i z pozostałego dorobku judykatury Sądu Najwyższego nie sposób jednak wywieść konstatacji tak daleko idącej, jak poglądy skarżącego, obstającego przy stanowisku, że wszelkie skracanie rdzenia firmy - nawet jednoznaczne, używane powszechnie w obrocie i lepiej rozpoznawalne na rynku - jest niedozwolone w obrocie prawnym (wekslowym). Przeciwnie, w orzecznictwie panuje stanowisko, że osoba prawna powinna być dostatecznie zindywidualizowana, a posługiwanie się nazwami handlowymi upowszechnionymi w obrocie masowym dopuszczalne (por. np. ww. wyrok Sądu Najwyższego z dnia 9 maja 2012 r.)" [podkr. T.T.].

Z zestawienia stanu faktycznego z wyżej przytoczonym fragmentem można próbować wyciągnąć wniosek, że SN stoi na stanowisku, iż dla ważności weksla wystarczające jest "dostateczne zindywidualizowanie" remitenta będącego osobą prawną. Podobną tezę w piśmiennictwie postawił już też Łukasz Węgrzynowski, jednak zaznaczył on, co ma istotne znaczenie, że odnośnie trzonu nazwy „mogą być dopuszczalne literówki i dodatki, niedopuszczalny jest natomiast skrót nazwy, chyba że dopuszczalność posługiwania się skrótem nazwy wynika wprost z ustawy"4.

W pierwszej kolejności należałoby się zastanowić, czy z przywołanych przez SN W analizowanym ostanowieniu orzeczeń, tj. wyroku V CSK $258 / 11^{5}$ oraz uchwały III CZP $54 / 13^{6}$ rzeczywiście wynika, że wystarczające jest, aby remitent będący osobą prawną na wekslu był jedynie „dostatecznie zindywidualizowany”.

Wyrok V CSK 258/11 dotyczył nieco podobnego stanu faktycznego i interpretacji niemalże tych samych przepisów ${ }^{7}$. Zasadnicza różnica $w$ okolicznościach sprawy jednak występowała. W postanowieniu został wykorzystany do oznaczenia remitenta nieujawniony w publicznym rejestrze skrót korpusu firmy. Natomiast w wyroku V CSK 258/11 przy oznaczeniu remitenta zabrakło oznaczenia jego formy prawnej, czyli obligatoryjnego składnika firmy. Różnica jest istotna, jednak nie sposób z wyroku V CSK 258/11 wyciągnąć wniosek, że SN postawił w nim tezę, iż dla ważności weksla

\footnotetext{
Ł. Węgrzynowski, Oznaczenie spółki kapitałowej na wekslu, ,,Przegląd Sądowy” 2017, nr 6, s. 44-45. 5 Wyrok SN z dnia 9 maja 2012 r., V CSK 258/11, OSNC 2013, z. 1, poz. 9 (dalej: wyrok V CSK 258/11).

6 Uchwała SN z dnia 10 października 2013 r., III CZP 54/13, OSNC 2014, z. 6, poz. 56 (dalej: uchwała III CZP 54/13).

7 Tj. art. 101 pkt 5 ustawy z dnia 28 kwietnia 1936 r. - Prawo wekslowe (Dz. U. z 2016 r., poz. 160; dalej: p.w., prawo wekslowe) oraz istotne przepisy ustawy z dnia 23 kwietnia 1964 r. - Kodeks cywilny (Dz. U. z 2020 r., poz. 1740 ze zm.; dalej: k.c.), dotyczące firmy przedsiębiorcy.
} 
wystarczające jest „dostateczne zindywidualizowanie” remitenta. W całym wyroku SN podkreśla, że remitent powinien być oznaczony w sposób precyzyjny i zgodnie z wymogami prawa firmowego. Wskazują na to liczne fragmenty orzeczenia, spośród których można wskazać:

„(...) W doktrynie jest prezentowane stanowisko, że nie powinno się nadmiernie formalizować obrotu prawnego i jeżeli podmiot będący osobą prawną jest wystarczająco zindywidualizowany, to mimo braku formy prawnej firmy nie należy traktować czynności prawnej z tej przyczyny za nieważną (...). Inaczej jednak należy podejść do czynności prawnych wyjątkowych, jednorazowych i w dodatku celowo, ustawowo sformalizowanych. Tak jest w wypadku czynności związanych z wystawieniem weksla i jest to powszechnie znane, zwłaszcza w obrocie profesjonalnym; (...) nie należy de lege lata aprobować nazw przedsiębiorców, które nie zawierają firmy według wymagań ustawowych. (...) Za chybione należy uznać twierdzenie, że w wypadku weksla można uczynić odstępstwo podobnie, jak w odniesieniu do nazw potocznie używanych w niesformalizowanych czynnościach prawnych, w których wystarczające jest rozpoznanie podmiotu dokonującego czynności. Wprawdzie może to grozić nieskutecznością zabezpieczenia wekslowego i nieuzyskanie spodziewanego świadczenia pieniężnego, ale strona powodowa sama spowodowała nieprawidłowe oznaczenie własnej firmy".

W wyroku tym brak wskazania na wekslu formy prawnej remitenta doprowadził do stwierdzenia jego nieważności. Główną tezą tego orzeczenia jest właśnie stwierdzenie, że weksel zawierający oznaczenie remitenta przez podanie nazwy przedsiębiorcy niestanowiącej jego firmy jest nieważny.

Uchwała III CZP 54/13 natomiast dotyczyła prawidłowego oznaczenia wystawcy weksla, a nie remitenta ${ }^{8}$. Rozważana była interpretacja art. 101 pkt 7 p.w., a nie art. 101 pkt 5 p.w. Zwraca na to uwagę nie tylko doktryna ${ }^{9}$, ale sam SN w omawianym orzeczeniu: „(...) należy bowiem zauważyć, że ustawodawca odmiennie określa wymagania formalne weksla własnego w art. 101 pkt 5 i 6 Pr.weksl., a odmiennie w art. 101 pkt 7 Pr.weksl. Bardziej kategorycznie ujęte są wymagania polegające na oznaczeniu w wekslu własnym remitenta oraz daty wystawienia weksla, aniżeli obowiązek opatrzenia dokumentu podpisem wystawcy weksla".

Tym samym, można się zastanawiać, czy w postanowieniu I CSK 716/17 SN prawidłowo powołał się na uchwałę III CZP 54/13, aby uzasadnić postawioną przez siebie tezę. Jeżeli już chciał takiego zabiegu dokonać, wydaje się, że powinien to uczynić

\footnotetext{
8 Różnicy tej nie zauważa też: R. Marek, Skutki braku pełnej firmy spółki kapitałowej na wekslu, „,Monitor Prawa Handlowego" 2015, nr 4, s. 33 i n.

9 W. Bendza prawidłowo zaznacza: „Przytoczenie przez SN wyroku z 9.05.2012 r. zbędnie przesłania istotę rozważań na temat podpisu (a przez to i oznaczenia) wystawcy, bowiem funkcja art. 101 pkt 5, tj. oznaczenie remitenta (której dotyczył ten wyrok) jest diametralnie inna niż wykładnia pojęcia podpisu wystawcy". Zob. W. Bendza, Podpis wystawcy weksla będq̨cego osoba prawnq. Glosa do uchwały SN z 10.10.2013 r., III CZP 54/13, PiP 2016, z. 1, s. 128. Można jednak znaleźć stanowiska przeciwne, wskazujące na potrzebę spójności prawa wekslowego. Zob. Ł. Węgrzynowski, Oznaczenie..., s. 42.
} 
w sposób bardziej rozbudowany. Powinien zaznaczyć, że mamy do czynienia z istotną różnicą w stanie faktycznym oraz interpretacją innego przepisu.

W postanowieniu I CSK 716/17 można również znaleźć powołanie się na „pozostały dorobek judykatury Sądu Najwyższego". Nie sposób jednak stwierdzić, jaki pozostały dorobek judykatury SN miał na myśli. Innych sygnatur w postanowieniu brak, a do wyroku V CSK 258/11, który odnosi się do kwestii oznaczenia remitenta, odwołują się bezpośrednio tylko cztery późniejsze orzeczenia $\mathrm{SN}^{10}$. Wydaje się, że aby uzasadnić postawioną przez SN w omawianym postanowieniu tezę, dużo bardziej zasadne byłoby powołanie się na orzeczenia dotyczące wykładni oświadczeń woli kreujących zobowiązania wekslowego ${ }^{11}$.

Podsumowując, z samego wyroku V CSK 258/11 z pewnością nie wynika teza, że dla uznania weksla za ważny, wystarczające jest "dostateczne zindywidualizowanie" remitenta. Natomiast uchwała III CZP 54/13 dotyczyła oznaczenia wystawcy weksla, a nie remitenta. Nie sposób też z samej treści postanowienia I CSK 716/17 stwierdzić, jaki pozostały swój dorobek SN miał na myśli. Tym samym, powołanie się przez SN na oba orzeczenia i bliżej niedookreślone orzecznictwo, w celu uzasadnienia swojego stanowiska, należy uznać za nie do końca poprawne.

Prawidłowość postawionej przez SN tezy można jednak próbować „ratować" przez odwołanie się do stanowisk występujących w piśmiennictwie i orzecznictwie ${ }^{12}$. Można wskazać występujące w literaturze rozróżnienie na oznaczenie remitenta i jego indywidualizację. Pierwsze - stanowi element formy wymaganej dla oświadczenia wystawcy weksla własnego ${ }^{13}$. Drugie - ma na celu jedynie ustalenie, kto jest osobą, której nazwę w tekście weksla zamieszczono (ewentualnie, czy w ogóle istnieje).

Jeżeli zaakceptuje się powyższe rozróżnienie, to łatwiej jest znaleźć spójność w wyżej analizowanych orzeczeniach. W wyroku V CSK 258/11 remitent nie został oznaczony prawidłowo, tj. nie doszło do wskazania podmiotu mającego zdolność wekslową. Tym samym, weksel nie mógł być uznany za ważny pod względem formy. W odniesieniu do uchwały III CZP 54/13, ze względu na podanie na wekslu numeru KRS, można było ustalić, że podmiot wystawiający miał zdolność wekslową, co prowadziło do ważności

\footnotetext{
$\overline{10}$ Poza uchwałą III CZP 54/13 i postanowieniem I CSK 716/17 są to: wyrok SN z dnia 15 grudnia 2017 r., III CSK 350/16, LEX nr 2439952 (który dotyczył głównie problemu oznaczenia remitenta będącego przedsiębiorcą zagranicznym, prowadzącego działalność w Polsce przez oddział) oraz postanowienie SN z dnia 28 czerwca 2018 r., I CSK 287/18, LEX nr 2522963, w którym SN krótko i w istocie na podstawie tych samych argumentów co w postanowieniu I CSK 716/17 odmawia przyjęcia skargi kasacyjnej do rozpoznania.

11 Zob. przykładowo uchwała SN z dnia 17 kwietnia 2015 r., III CZP 11/15, OSNC 2016, z. 4, poz. 42. Więcej na ten temat poniżej.

12 S. Wróblewski, Prawo wekslowe i czekowe, Kraków 1936, s. 30-32, s. 37, s. 349; I. Rosenblüth, Prawo wekslowe i czekowe. Komentarz, t. 1, Kraków 1936, s. 68-69, s. 80-81, s. 88; J. Jastrzębski [w:] idem, M. Kaliński, Prawo wekslowe i czekowe. Komentarz, Warszawa 2014, s. 78, s. 82, s. 92 oraz uchwała SN z dnia 6 kwietnia 2017 r., III CZP 117/16, OSNC 2018, z. 1, poz. 6. Literatura ta i orzeczenia nie zostały wskazane $\mathrm{w}$ omawianym postanowieniu.

13 Niezbędny dla uznania dokumentu za weksel. Zob. uchwała SN z dnia 17 kwietnia 2015 r., III CZP 11/15, OSNC 2016, z. 4, poz. 42.
} 
weksla pod względem formy. Powstał jedynie problem indywidualizacji, która powinna odbyć się w ramach przyjętych reguł wykładni weksla.

Wprowadzając wspomniane rozróżnienie i zwracając uwagę na stan faktyczny sprawy, można bronić poprawności tezy postawionej w postanowieniu I CSK 716/17. Należy jednak wyraźnie zaznaczyć, że wyrok V CSK 258/11 wskazanego rozróżnienia w ogóle nie czyni. Uchwała III CZP 54/13 dotyczyła oznaczenia wystawcy, a nie remitenta, i sama treść orzeczenia wyraźnie wskazuje, że wymogów co do oznaczenia wystawcy i remitenta nie należy utożsamiać ${ }^{14}$. Co więcej, pogląd nakazujący wyraźnie odróżnienie oznaczenia remitenta od jego indywidualizacji, wraz z wyżej przytoczonym dookreśleniem tych pojęć, do powszechnych zdaje się nie należeć ${ }^{15}$. Tym samym, konsekwentnie należy twierdzić, że przywołane w postanowieniu orzeczenia stanowią nie najlepsze uzasadnienie tezy w nim postawionej. Nawet jeżeli omawiane orzeczenia „harmonizują" z poglądami doktryny, to tylko na skutek próby ich interpretacji zgodnie z tymi poglądami. Sąd Najwyższy w postanowieniu I CSK 716/17 nie tyle powinien jedynie wskazać na te dwa orzeczenia, co zwrócić uwagę na wskazane poglądy doktryny lub inaczej i szerzej uzasadnić swoje stanowisko. Obecnie mamy postanowienie I CSK 716/17, które stawia stosunkowo śmiałą i może zgodną z poglądami doktryny tezę, ale uzasadnioną wyrokami, z których ona bezpośrednio nie wynika. Każdy próbujący wyprowadzić tezę postawioną przez SN w tym postanowieniu na podstawie samego wyroku V CSK 258/11 i uchwały III CZP 54/13 będzie miał z tym problem. Postanowienie stanowi jednak dobry kontekst, aby szerzej rozważyć kwestie oznaczenia remitenta będącego spółką handlową.

W wyroku V CSK 258/11 SN postawił tezę, że nieważny jest weksel zawierający oznaczenie remitenta przez podanie nazwy przedsiębiorcy niestanowiącej jego firmy. W niniejszej glosie w pierwszej kolejności można się zastanowić, jak do rzeczonej tezy doszedł.

Zgodnie z art. 101 pkt 5 p.w. weksel własny powinien zawierać nazwisko osoby, na której rzecz lub na której zlecenie zapłata ma być dokonana ${ }^{16}$. Z literalnego brzmienia przepisu wynika, że remitentem powinna być osoba fizyczna. W piśmiennictwie i orzecznictwie nie budzi jednak wątpliwości, że może nim być również spółka prawa

\footnotetext{
14 „Należy przy tym podkreślić, że surowe wymagania dotyczące oznaczenia remitenta - wymagające w szczególności oznaczenia jego formy prawnej zgodnie z art. 435 § 2 k.c. - w świetle poglądów judykatury nie muszą znajdować zastosowania do oznaczenia wystawcy weksla. Orzecznictwo wskazuje na konieczność bardziej rygorystycznego podejścia do sposobu oznaczenia remitenta niż wystawcy weksla". Zob. J. Jastrzębski [w:] idem, M. Kaliński, Prawo..., komentarz do art. 1 pkt 15 p.w. 15 Wyraźnie nie występuje - zob. np.: J. Jastrzębski [w:] idem, M. Kaliński, Prawo..., komentarz do art. 1 oraz art. 101 p.w. Zob. też: uchwałę SN z dnia 6 kwietnia 2017 r., III CZP 117/16, OSNC 2018, z. 1, poz. 6 . W uchwale tej nie zostało wprowadzone rozróżnienie na "oznaczenie remitenta" $i$,jego indywidualizację". Sąd Najwyższy zwyczajnie stwierdził ważność weksla, na którym, w odniesieniu do remitenta, zabrakło dookreślenia, że jest to „Skarb Państwa”. SN postawił jedynie dosyć generalną tezę, że „nie można uznać wymaganej przez prawo wekslowe formy za niespełnioną we wszystkich tych wypadkach, w których całość tekstu weksla nie pozostawia w toku jego wykładni wątpliwości, iż jest on zgodny pod względem formy z właściwymi przepisami". Był to też stan faktyczny inny niż womawianej sprawie.

16 W odniesieniu do weksla trasowanego, zob. art. 1 pkt 6 p.w.
} 
handlowego ${ }^{17}$. Takie stwierdzenie nie rozwiązuje jednak podstawowego dla niniejszych rozważań problemu, tj. kwestii, w jaki sposób na wekslu oznaczyć remitenta będącego osobą prawną lub spółką handlową. Przywołany przepis, ani żaden inny artykuł prawa wekslowego, wskazówek w tym zakresie nie daje.

Z literalnego brzmienia art. 101 pkt 5 p.w. można jednak wyciągnąć wniosek, który będzie miał istotne znaczenie dla dalszych rozważań. Przepis bezsprzecznie wskazuje, że remitent będący osobą fizyczną nie musi być oznaczony w sposób precyzyjny. Podanie samego nazwiska na wekslu w zdecydowanej większości przypadków nie zindywidualizuje danego remitenta. Uwagę na to zwraca SN w wyroku V CSK 258/11, zauważając, że stan taki w literaturze „tłumaczy się (...) dość lakonicznie, jako wystarczające przy podaniu tylko nazwiska zidentyfikowanie w konkretnych okolicznościach osoby, o którą chodzi". W piśmiennictwie i orzecznictwie zatem przeważa stanowisko, że w przypadku remitentów będącymi osobami fizycznymi wystarczające jest „niewątpliwe zindywidualizowanie"18.

Należy jednak ponownie zaznaczyć, że prawo wekslowe w żaden sposób nie wskazuje, w jaki sposób należałoby oznaczyć na wekslu remitenta będącego spółką handlową. Zgodnie z powyższym, skoro w przypadku osób fizycznych wystarczające jest dostateczne zindywidualizowanie, podobnie powinno być w przypadku spółek handlowych.

Występuje jednak istotna różnica. W odniesieniu do osób fizycznych te wymogi, co prawda jedynie w minimalnym stopniu, są określone. W odniesieniu do osób prawnych brak jest ustawowego minimum. Można się zastanawiać, czy w ich przypadku generalne stwierdzenie, że wystarczające jest „dostateczne zindywidualizowanie”, nie rodzi więcej problemów, niż ich rozwiązuje. Zwłaszcza że w polskim porządku prawnym mamy do czynienia z teorią normatywną osób prawnych. Dlatego pewnych minimalnych standardów należałoby poszukać. Powstaje oczywiście pytanie: gdzie? Kierunek poszukiwań obrany przez SN w wyroku V CSK 258/11 jest prawidłowy. Zgodnie z nim, w pierwszej kolejności należy zwrócić uwagę na przepisy ogólne prawa cywilnego dotyczące osób prawnych (art. 33-43 k.c.), przepisy dotyczące oznaczenia przedsiębiorcy (art. $43^{1}-43^{10}$ k.c.) oraz ewentualnie, przepisy szczególne dotyczące konkretnej kategorii osób prawnych ${ }^{19}$.

Przepisy ogólne prawa cywilnego dotyczące osób prawnych (art. 33-43 k.c.) nie zawierają regulacji odnośnie oznaczania osób prawnych. W doktrynie i orzecznictwie zaznacza się jednak, że art. 37 k.c. stanowi o właściwych rejestrach, które regulują

\footnotetext{
17 Zob. przykładowo: Ł. Węgrzynowski, Oznaczenie..., s. 37-46.

18 W wyroku V CSK 258/11 Sąd Najwyższy zaznacza, że taka teza może budzić wątpliwości w przypadku osób fizycznych będących przedsiębiorcami. Tezę, że wystarczające jest niewątpliwe zindywidualizowanie remitenta będącego osobą fizyczną można znaleźć m.in. w orzeczeniu SN z dnia 14 października 1931 r., Rw 1592/31, OSP 1931, z. 1, poz. 543 oraz publikacji: A. Szpunar, Komentarz do prawa wekslowego i czekowego, Warszawa 2001, komentarz do art. 1, nt 7.

19 Jeżeli w przypadku konkretnej kategorii osób prawnych takie przepisy szczególne dotyczące oznaczenia występują. Zob. przykładowo art. 305 ustawy z dnia 15 września 2000 r. - Kodeks spółek handlowych (Dz. U. z 2020 r., poz. 1526 ze zm.) w przypadku spółki akcyjnej.
} 
przepisy odrębne. Natomiast już w owych przepisach odrębnych, tj. przede wszystkim w ustawie z dnia 20 sierpnia 1997 r. o Krajowym Rejestrze Sądowym ${ }^{20}$, wyraźnie odróżnia się nazwę i firmę przedsiębiorcy ${ }^{21}$. Nazwa stanowi oznaczenie także tych osób prawnych, które nie są przedsiębiorcami, więc pod tym względem jest pojęciem szerszym od firmy ${ }^{22}$. Brak jest przepisów prawa cywilnego, które dotyczyłyby nazwy osoby prawnej, co otwiera pole do dyskusji co do jej konstrukcji, i tym samym jej wykorzystania przy oznaczeniu remitenta. Biorąc jednak pod uwagę stan faktyczny z postanowienia I CSK 716/17 oraz fakt, że w zdecydowanej większości sytuacji, w przypadku wystawienia weksla i jego remitenta będziemy mieli do czynienia z przedsiębiorcą, analiza oznaczenia osób prawnych lub spółek kapitałowych niebędących przedsiębiorcami może zostać w niniejszej glosie pominięta. Ze względu na powyższe, dalej w niniejszej glosie, gdy będzie mowa o spółce handlowej, przyjmuje się, że jest ona przedsiębiorcą.

Natomiast posiadanie przez daną spółkę handlową przymiotu przedsiębiorcy sprawia, że znajdują zastosowanie przepisy dotyczące jego oznaczenia, tj. przede wszystkim art. $43^{2}-43^{10}$ k.c. Nie sposób znaleźć przekonujących argumentów, aby przy oznaczeniu remitenta regulacje te nie znajdowały zastosowania ${ }^{23}$. Podsumowując, na tym etapie rozważań należy postawić tezę, że ze względu na brak określenia w przepisach prawa wekslowego minimalnych standardów oznaczenia na wekslu remitenta będącego spółką handlową, art. $43^{2}-43^{10}$ k.c. powinny być co najmniej wzięte pod uwagę przy jego oznaczeniu.

Wyżej postawiona teza celowo jest dosyć niedookreślona. Aby wypowiedź w odniesieniu do analizowanego zagadnienia była bardziej kategoryczna, należy rozważyć, czy główną tezę z wyroku V CSK 258/11 należałoby ciągle uważać za aktualną. Innymi słowy, można się szerzej zastanowić, czy powinniśmy stać twardo na stanowisku, że weksel zawierający oznaczenie remitenta przez podanie nazwy przedsiębiorcy niestanowiącej jego firmy jest nieważny.

Za zliberalizowaniem wymogu odnośnie oznaczenia remitenta przemawiają przede wszystkim dwa argumenty. Po pierwsze, argument, że nie powinno się nadmiernie formalizować obrotu prawnego, gdyż za łatwo dawałoby to pretekst nieuczciwym kontrahentom do nietrudnego doprowadzania do nieważności czynności prawnej, tylko ze względu na nieprawidłowe oznaczenie przedsiębiorcy ${ }^{24}$. Po drugie, że w przypadku remitentów będących osobami fizycznymi wystarczające jest w istocie

20 Dz. U. z 2021 r. poz. 112 ze zm.; dalej u.k.r.s.

21 Zob. przykładowo art. 34 ust. 1 pkt 1 u.k.r.s.

22 Podobnie: M. Tarska [w:] Komentarz do art. 1-60 ustawy o Krajowym Rejestrze Sadowym. Kodeks spółek handlowych. Pozakodeksowe prawo handlowe. Komentarz, t. 5, red. S. Sołtysiński, A. Szajkowski, A. Szumański, J. Szwaja, Warszawa 2015, komentarz do art. 34 u.k.r.s., nt 2-4.

23 Szeroko na ten temat: M. Dziadzio, P. Ochwat, Dopuszczalność skracania korpusu firmy spółki kapitałowej w świetle przepisów kodeksu cywilnego, kodeksu spółek handlowych oraz ustawy o krajowym rejestrze sądowym , Acta Scientifica Academiae Ostroviensis, sectio A, Nauki Humanistyczne, Społeczne i Techniczne" 2016, nr 8, s. 418-431.

24 Taki argument w istocie możemy znaleźć w wyroku V CSK 258/11 oraz u Ł. Węgrzynowskiego [w:] idem, Oznaczenie..., s. 37 i n. 
ich dostateczne zindywidualizowanie. Tym samym, nieuzasadnione jest stawianie wyższych wymogów w stosunku do spółek handlowych.

Pierwszy z tych argumentów stosunkowo łatwo zbić i w zasadzie wystarczające jest posłużenie się argumentami z wyroku V CSK 258/11. O ile na gruncie „standardowego" obrotu cywilnego przywołany argument można uznać za istotny, traci on na mocy w przypadku prawa wekslowego. Słabą częścią uzasadnienia postanowienia I CSK 716/17 jest zupełny brak dostrzeżenia różnicy pomiędzy obrotem zwykłym a wekslowym. Jak zaznacza SN w wyroku V CSK 258/11, obrót wekslowy jest celowo ustawowo sformalizowany. Dodatkowo wystawienie weksla jest czynnością jednorazową i wyjątkową. W piśmiennictwie wyraźnie zaznacza się, że „od początku obrót wekslowy cechował tzw. rygor wekslowy, przejawiający się m.in. w szybkiej, uproszczonej i bardzo skutecznej egzekucji należności wekslowych"25. Innymi słowy, ów rygoryzm stanowi trzon prawa wekslowego, a wyjątki od niego powinny mieć silne uzasadnienie. Można się zastanawiać, czy powinny się opierać na braku staranności remitenta, która później utrudniałaby jego zindywidualizowanie. W omawianym kontekście w literaturze dodatkowo zaznacza się, że obrót wekslowy w znacznie większym stopniu niż prawo cywilne cechuje m.in. ograniczenie „opiekuńczej" roli norm prawnych czy podniesienie rangi profesjonalizmu w obrocie ${ }^{26}$. Jak już prawie wiek temu podkreślał Antoni Górski, „jeśli weksel ma się cieszyć takim zaufaniem w obrocie, jak srebro i złoto, to prawo wekslowe musi być tak twarde, jak te metale"27.

Drugi argument już tak łatwy do zbicia nie jest. Skoro w przypadku osób fizycznych wystarczające jest dostateczne zindywidualizowanie remitentów, to może także nie powinno się zbyt rygorystycznie podchodzić do wymogów prawa firmowego. Innymi słowy, pewne nieścisłości w oznaczeniu remitenta będącego spółką handlową nie powinny prowadzić do nieważności weksla, o ile jest się go w stanie ciągle zindywidualizować w ramach dopuszczalnych reguł wykładni zobowiązania wekslowego. Rodzi się pytanie, dlaczego spółki handlowe powinny być traktowane gorzej niż osoby fizyczne, tj. dlaczego w stosunku do nich występowałby „podwyższony” standard staranności oznaczenia. Innymi słowy, powstaje wątpliwość, z jakiej racji w przypadku osób fizycznych, przynajmniej w pewnym ograniczonym zakresie, możemy się "domyślać", kto jest remitentem, ale w przypadku spółek kapitałowych już nie, ponieważ firma musi być podana bardziej precyzyjnie? Podobnego rodzaju i nawet bardziej rozbudowaną argumentację możemy znaleźć $u \nmid$. Węgrzynowskiego ${ }^{28}$. Nie sposób odmówić mocy takim argumentom, co może skłaniać do stwierdzenia, że teza z postanowienia I CSK 716/17 o dostatecznej indywidualizacji remitenta, zwłaszcza przy wprowadzeniu ww. rozróżnienia na oznaczenie remitenta i jego indywidualizację, jest jednak słuszna.

W ramach akademickiej debaty można się jednak zastanowić nad kontrargumentami w stosunku do wspomnianej tezy.

\footnotetext{
25 M. Koziński, J. Dybiński [w:] System Prawa Prywatnego, t. 18, Prawo papierów wartościowych, red. A. Szumański, Warszawa 2016, s. 174.

26 Zob. ibidem, s. 184.

27 A. Górski, Prawo wekslowe i czekowe, Warszawa 1925, s. 168.

28 Ł. Węgrzynowski, Oznaczenie..., s. 43-44.
} 
Po pierwsze, wyżej przedstawiona racja o podwyższonym standardzie staranności nie wypada tak mocno, jeżeliby zwrócić uwagę, że firmę posiadają jedynie przedsiębiorcy. Zasadą jest, że od przedsiębiorców można wymagać owego podwyższonego standardu (art. 355 § 2 k.c.). W praktyce zwykle to remitent będzie podmiotem przygotowującym treść weksla. Natomiast nawet w przypadku, w którym weksel byłby przygotowywany przez wystawcę, remitent powinien mieć możliwość weryfikacji jego treści i zgłoszenia ewentualnych uwag ${ }^{29}$. Należy też zaznaczyć, że przedsiębiorcy powinni zdawać sobie sprawę, że weksel jest papierem wartościowym o wysokich standardach formalnych ${ }^{30}$.

Po drugie, można ponownie powołać się na celowe sformalizowanie obrotu wekslowego przez ustawodawcę. Brak restrykcyjnego podejścia do przestrzegania wymogów prawa firmowego, otwierałby pole do dyskusji, jaki jest minimalny standard oznaczenia remitenta będącego spółką handlową i jakie są granice dopuszczalnej wykładni. Do prawa wekslowego, które z założenia miało być sformalizowane, wprowadzałoby się element ocenny. Jak, może nieco na wyrost, zaznacza SN w wyroku V CSK 258/11, „otworzyłaby się nieograniczona możliwość manipulowania treścią papierów wartościowych, a następnie innych czynności odnośnie do oznaczania podmiotów w nich uczestniczących, byle możliwe było ich zindywidualizowanie". W świetle powyższego, uzasadnione wydaje się wymaganie od remitenta, aby ten, gdy sporządza czy wypełnia weksel, dokładnie zweryfikował, czy został wskazany w sposób precyzyjny, tj. zgodnie ze swoją firmą. Możemy dzięki temu uniknąć nieraz skomplikowanych i złożonych sporów interpretacyjnych, co wpływa pozytywnie na szybkość i pewność obrotu wekslowego. Każdy prawnik zamiast udzielić niestety zbyt częstej w praktyce odpowiedzi: „to zależy”, będzie w stanie momentalnie ocenić, czy weksel pod tym względem jest ważny. Wprowadzanie rozróżnienia na „oznaczenie remitenta”i jego „indywidualizację", choć raczej ugruntowane w doktrynie i orzecznictwie, jest o tyle kontrowersyjne, że pojęciami takimi przepisy prawa wekslowego się nie posługują. Tym samym, konsekwentnie, powstaje pytanie o prawidłowe zdefiniowanie tych terminów.

Po trzecie, należy pamiętać o bardzo surowej odpowiedzialności wekslowej. Weksel tworzy zobowiązanie abstrakcyjne i bezwarunkowe ${ }^{31}$. Tak mocno podkreślany formalizm sam w sobie mógłby budzić wątpliwości, gdyby nie wspomniane cechy tego zobowiązania. Zatem łagodzenie formalizmu bez jednoczesnego „Iuzowania” abstrakcyjności i bezwarunkowości może rodzić zastrzeżenia. Natomiast łagodzenie wszystkich tych cech naraz prowadzi do tego, że zobowiązanie wekslowe przestaje się różnić od klasycznego zobowiązania cywilnoprawnego.

\footnotetext{
29 Powstaje oczywiście problem, czy rzeczonego podwyższonego standardu staranności można wymagać od osoby fizycznej będącej przedsiębiorcą. Ze względu na brzmienie art. 101 pkt 5 p.w. wydaje się, że teza taka jest nieuzasadniona. Problem ten nie stanowi jednak przedmiotu niniejszej glosy i wydaje się, że zasługuje na szersze rozważania.

30 Podobnie: SN w wyroku V CSK 258/11.

31 Więcej na temat bezwarunkowości i abstrakcyjności zobowiązania wekslowego zob. M. Koziński, J. Dybiński, [w:] Prawo..., s. 201-202 oraz s. 207-210.
} 
Po czwarte, należy zwrócić uwagę na zagadnienie pewności i bezpieczeństwa obrotu. Nieprawidłowo wpisana firma remitenta sprawi, że podmiot, który będzie chciał wstępnie zweryfikować remitenta będącego spółką handlową, nie będzie mógł znaleźć go w internetowej wyszukiwarce KRS ${ }^{32}$. Tym samym, nabywca weksla nie będzie w stanie łatwo ocenić, czy nabywa ważny weksel. Osłabia to jedną z podstawowych funkcji weksla, jaką jest jego funkcja obiegowa ${ }^{33}$. Słuszne Włodzimierz Bendza zauważa, że „ustawodawca, stawiając w przepisach art. 1 i art. 101 warunki formalne, miał bez wątpienia na względzie sprawność i bezpieczeństwo obrotu wekslowego" ${ }^{\prime 34}$. Podobne tezy możemy znaleźć w orzecznictwie SN, gdzie zwraca się uwagę na przeznaczenie weksla do obiegu ${ }^{35}$.

Podsumowując, w wyroku V CSK 258/11 została postawiona teza, że nieważny jest weksel zawierający oznaczenie remitenta przez podanie nazwy przedsiębiorcy niestanowiącej jego firmy. Rzeczoną tezę można uznać za aktualną, ale nie dookreśla ona jednak, jak precyzyjnie owa firma powinna być wskazana. W doktrynie ugruntowany jest pogląd, że należy odróżnić oznaczenie remitenta od jego indywidualizacji. Takie założenie pozwala na wskazanie remitenta w sposób nie do końca precyzyjny, o ile zamieszczone w dokumencie oznaczenie wskazuje na podmiot mogący mieć zdolność wekslową (oznaczenie), a w ramach późniejszej indywidualizacji uda się remitenta dostatecznie zindywidualizować.

Można jednak też znaleźć pewne argumenty, aby w przypadku spółek handlowych będących przedsiębiorcami wspomnianego rozróżnienia na „oznaczenie” i „,indywidualizację" nie wprowadzać, a remitent powinien być po prostu oznaczony w sposób zgodny ze swoją firmą ujawnioną w rejestrze ${ }^{36}$. Innymi słowy, prawidłowego brzmienia jego firmy nie powinniśmy się „domyślać” nawet w ramach dopuszczalnej wykładni weksla.

Nawet jeżeli zgodzilibyśmy się z wyżej zaprezentowaną i kontrowersyjną tezą, że remitent powinien być oznaczony w sposób zgodny ze swoją firmą i to w sposób, w jaki taka firma została ujawniona w rejestrze, to w stanie faktycznym z glosowanego postanowienia można wskazać inny ciekawy problem. Remitent został oznaczony za pomocą skrótu. W przypadku, w którym byłby to „nieoficjalny” skrót, istniałyby dodatkowe argumenty za nieważnością takiego weksla, gdyż można by próbować twierdzić, że remitent nie został nawet "dostatecznie zindywidualizowany" ${ }^{\prime 37}$. Jednak

\footnotetext{
32 Przynajmniej w przypadkach, w których remitent nie będzie dookreślony przez inne cechy i będzie się próbowało go znaleźć po nieprecyzyjnie wskazanej nazwie.

33 Więcej na temat funkcji obiegowej weksla zob. M. Koziński, J. Dybiński [w:] Prawo..., s. 213-214.

34 W. Bendza, Podpis..., s. 126. W doktrynie zaznacza się również, że KRS powinien stanowić podstawowe źródło do weryfikacji, czy podmiot istnieje. Zob. M. Wrzołek-Romańczuk, "Wpis niedopuszczalny" w Krajowym Rejestrze Sądowym, PPH 2002, nr 4, s. 2 oraz M. Dziadzio, P. Ochwat, Dopuszczalność..., s. 429.

35 Zob. uchwała SN z dnia 17 kwietnia 2015 r., III CZP 11/15, OSNC 2016, z. 4, poz. 42.

36 Podobną tezę można znaleźć np. w wyroku SA w Katowicach z dnia 28 lutego 2005 r., I ACa 1554/04, LEX nr 151736.

37 W wyroku SA w Katowicach z dnia 28 lutego 2005 r., I ACa 1554/04, LEX nr 151736, można przeczytać: „1. Podmioty niebędące osobami fizycznymi powinny posługiwać się w obrocie wekslowym nazwą (firmą) w takim brzmieniu, w jakim została ujawniona w rejestrze. 2. Użycie skrótu, który może
} 
stan faktyczny był bardziej złożony. Remitent został oznaczony za pomocą skrótu, który występował w jego statucie, ale nie został wpisany do KRS. Innymi słowy, remitent był oznaczony niezgodnie z wpisem. Czy takie oznaczenie remitenta jest niezgodne z prawem firmowym?

Zgodnie z art. $43^{5} \S 4$ k.c., przedsiębiorca może posługiwać się skrótem firmy, a przepis art. $43^{2} \S 2$ k.c. stosuje się odpowiednio. Artykuł $43^{2} \S 2$ k.c. stanowi natomiast, że firmę ujawnia się we właściwym rejestrze, chyba że przepisy odrębne stanowią inaczej. Na gruncie wyłącznie owych dwóch przepisów można dojść do wniosku, że oznaczenie remitenta za pomocą skrótu byłoby dopuszczalne tylko w przypadku, w którym ów skrót został ujawniony we właściwym rejestrze ${ }^{38}$. Można by zatem próbować twierdzić, że weksel, w którym remitent został ujawniony za pomocą skrótu, którego nie można znaleźć we wpisanych do rejestru danych, jest nieważny. Pośrednio w takim tonie zdaje się wypowiadać SN w wyroku V CSK 258/11: „Zarówno firmę (...), jak i ewentualny skrót firmy przedsiębiorca ma obowiązek ujawnić w rejestrze przedsiębiorców (...). Zgodnie z przytoczonym orzecznictwem powinien posłużyć się firmą według wpisu do rejestru". Problem jednak jest bardziej złożony.

Jak już zaznaczono, art. $43^{5} \S 4$ k.c. dopuszcza posługiwanie się skrótem, co jest praktyczne i często stosowane przez spółki w umowach i statutach ${ }^{39}$. W zwykłym obrocie posługiwanie się takimi skrótami raczej nie budzi większych wątpliwości ${ }^{40}$. Co więcej, takie statuty czy umowy przy wpisie spółki do rejestru są do niego składane. Problem polega na tym, że obecne przepisy u.k.r.s. nie dopuszczają wpisania do rejestru skrótu ${ }^{41}$. Tym samym, choć spółka handlowa jest zgodnie z k.c. uprawniona do obrania skrótu swojej firmy, to nie jest w stanie go wpisać do rejestru i w pełni ujawnićc ${ }^{42}$. Innymi słowy,

wprowadzać wątpliwości co do osoby remitenta w obrocie wekslowym, czyni weksel nieważnym". Tezy te wydają się nieco sprzeczne, ponieważ może powstać wątpliwość, czy jeżeli posłużono się skrótem nieujawnionym w rejestrze, który nie wprowadza w błąd, to weksel należałoby uważać za ważny. Tak, wydaje się: A. Szpunar, M. Kaliński, Komentarz do prawa wekslowego i czekowego, Warszawa 2003, s. 64.

38 Chyba że istniałby przepis odrębny, zezwalający na posługiwanie się skrótem mimo braku jego ujawnienia.

39 Szerzej na temat skracania firmy, zob. P. Zaporowski, Zalety i wady unormowania skracania firm w art. 43(5) § 4 k.C., ,Kwartalnik Prawa Prywatnego" 2006, nr 4, s. 909-952. Odnośnie zapotrzebowania praktyki na możliwość skracania korpusów firm spółek handlowych, zob. R. Stefanicki, Prawo do nazwy (firmy) i jego ochrona „,Prawo Spółek” 1999, nr 2, s. 19.

${ }^{40}$ Choć można znaleźć też dosyć ogólne opinie, że możliwość posługiwania się skrótem jest uzależniona od jego zarejestrowania. Zob. E. Gniewek [w:] Kodeks cywilny. Komentarz, red. idem, P. Machnikowski, Warszawa 2013, s. 106-107. Akceptacja takiej tezy prowadziłaby do wniosku, że posługiwanie się skrótem firmy, ze względu na brak możliwości jego rejestracji, jest obecnie niemożliwe.

41 Szeroko na ten temat m.in.: P. Zaporowski, Zagadnienie rejestracji skrótu firmy [w:] Księga dla naszych Kolegów. Prace prawnicze poświęcone pamięci doktora Andrzeja Ciska, doktora Zygmunta Masternaka, doktora Marka Zagrosika, red. J. Mazurkiewicz, Wrocław 2013, s. 477-487; R. Adamus, W sprawie dopuszczalności skracania korpusu spółki kapitałowej, "Rejent” 2012, nr 6; idem, Dopuszczalność skracania korpusu spółki kapitałowej, „Prawo Spółek” 2012, nr 9.

42 Skrót w pewnym stopniu jest ujawniany, gdyż akta rejestrowe, w tym zatem statut czy umowa spółki, są dostępne dla osób trzecich. Mówi się w tym przypadku o ujawnieniu przez „złożenie dokumentów". Zob. P. Zaporowski, Zagadnienie..., s. 481-482, przypis 18. 
przepisy k.c. nakładają obowiązek, którego przepisy u.k.r.s. nie pozwalają zrealizować. Mamy tutaj zatem do czynienia z niespójnością kodeksowego prawa firmowego z przepisami rejestrowymi. Należy się zastanowić, czy to sprawia, że weksel, na którym remitent został oznaczony za pomocą skrótu nieujawnionego we wpisie, ale obranego w umowie czy statucie spółki, jest ważny.

Wydawałoby się, że skoro to ustawodawca nie zezwala na pełne ujawnienie skrótu, to nie sposób winić przedsiębiorcy, że go nie ujawnił. Tym samym, nie sposób nakładać na niego tak rygorystyczną sankcję jak nieważność weksli, w których jako remitent został ujawniony za pomocą skrótu, którym zwyczajowo w obrocie się przecież posługuje, i który występuje w jego akcie kreacyjnym ${ }^{43}$. W takim tonie zdaje się wypowiadać sąd w wyroku I ACa 2148/15 $5^{44}$. Niezależnie jednak od owych argumentów, „uratować” ważność takiego weksla można przez przyjęcie rozróżnienia na oznaczenie remitenta i jego indywidualizację. Zakładając, że skrót firmy to nie to samo co firma, należałoby stwierdzić, że remitent został oznaczony niezgodnie ze swoją firmą. Jednak występujące na wekslu skrótowe oznaczenie wskazuje na podmiot mogący mieć zdolność wekslową (kwestia oznaczenia), co oznacza, że weksel powinien być uznany za ważny pod względem formy. Natomiast w ramach indywidualizacji możliwe byłoby ustalenie, czy remitent istnieje i kto nim jest.

Natomiast gdyby przyjąć kontrowersyjną tezę, że remitent powinien być oznaczony w sposób zgodny ze swoją firmą ujawnioną w rejestrze, to oznaczenie remitenta za pomocą samego skrótu nieujawnionego we wpisie do rejestru jest niedopuszczalne i taki weksel należałoby uważać za nieważny ${ }^{45}$. Nad ważnością weksla można by ewentualnie się zastanawiać w przypadku, w którym prócz skrótu na wekslu podany byłby np. numer KRS ${ }^{46}$. Można się jednak zastanowić, jakie argumenty przemawiają za tak rygorystyczną tezą o nieważności weksla.

Po pierwsze, takie oznaczenie remitenta nie będzie pozwalało na odnalezienie go w wyszukiwarce KRS, co wpływa negatywnie na pewność obrotu. Wyszukiwarka KRS stanowi podstawowe narzędzie do wstępnej weryfikacji spółki handlowej. Tym samym, wpływa to też negatywnie na funkcję obrotową weksla, zwłaszcza w przypadku jego wielokrotnego zbywania. Podanie firmy występującej w KRS pozwala zapewnić bezproblemową identyfikację remitenta ${ }^{47}$. Z punktu widzenia pewności obrotu powsta-

\footnotetext{
43 R. Adamus zwraca jednak uwagę, że zdarzają się sytuacje, że „sądy rejestrowe odmawiają rejestracji umów spółek z o.o. i statutów spółek akcyjnych w takim zakresie, w jakim owe akty ustrojowe wprowadzają skróty korpusu firmy spółki kapitałowej"; idem, Dopuszczalność..., s. 48.

44 Choć należy zaznaczyć, że Sąd Apelacyjny w tym przypadku uznał też, że art. 38 u.k.r.s. to przepis szczególny w rozumieniu art. $43^{2} \S 2$ k.c., który stanowi inaczej. Na paradoksalność tego rodzaju interpretacji wskazuje P. Zaporowski, Zagadnienie..., s. 482.

45 Podobnego rodzaju tezę można znaleźć w wyroku SA w Katowicach z dnia 28 lutego 2005 r., I ACa 1554/04, LEX nr 151736, w którym możemy przeczytać, że podmioty niebędące osobami fizycznymi powinny posługiwać się w obrocie wekslowym nazwą (firmą) w takim brzmieniu, w jakim została ujawniona $w$ rejestrze.

46 Jak podkreśla Ł. Węgrzynowski, numer KRS „ma wartość identyfikacyjną, może zatem łagodzić pewne braki w treści firmy podanej na wekslu”, zob. idem, Oznaczenie..., s. 45.

47 Podobnie, ale w nieco innym kontekście: P. Popardowski [w:] Ustawa o Krajowym Rejestrze Sądowym. Komentarz, red. K. Osajda, Warszawa 2020, komentarz do art. 34, nt 2.
} 
je pytanie, dlaczego brak podania formy prawnej miałby prowadzić do nieważności weksla, ale podanie skrótu firmy już niekoniecznie? Jeżeli w elektronicznej wyszukiwarce KRS wpisze się fragment firmy bez określenia jej formy prawnej, to taki podmiot zwykle da się znaleźć ${ }^{48}$. Natomiast jeżeli wpisze się skrót nazwy, to podmiotu, którego się szukało, nie da się znaleźć. Powstaje logiczne pytanie, która z tych sytuacji jest lepsza dla pewności i szybkości obrotu wekslowego?

Po drugie, liberalizując oznaczenie remitenta, jest się bardzo blisko stosunkowo niebezpiecznej tezy, którą SN wyraził w postanowieniu I CSK 716/17, tj. stwierdzenia, że „osoba prawna powinna być dostatecznie zindywidualizowana, a posługiwanie się nazwami handlowymi upowszechnionymi w obrocie masowym dopuszczalne". Takie stanowisko faworyzowałoby duże podmioty o już ugruntowanej pozycji rynkowej, których nazwa handlowa może być uznana za "upowszechnioną w obrocie masowym". Dyskryminowałoby natomiast małe czy nowe podmioty, które dopiero walczą o zaistnienie w takim obrocie. Byłoby to więc stanowisko odwrotne od ostatnio przyjmowanego przez polskiego ustawodawcę, który stara się chronić małe podmioty, słusznie dostrzegając korzyści, jakie zwykle idą za przewagą kapitałową tych dużych ${ }^{49}$.

Po trzecie, należy zaznaczyć, że czynność polegająca na oznaczeniu remitenta jest wyjątkowa i jednorazowa. Przedsiębiorcy doskonale powinni zdawać sobie sprawę, że skrót ich firmy nie jest obecnie ujawniony w rejestrze. Wpisanie pełnej firmy zamiast jej skrótu kosztuje przedsiębiorcę zaledwie kilka dodatkowych sekund, a korzyści dla obrotu są znaczne. Możemy dzięki temu uniknąć złożonego i skomplikowanego procesu związanego z indywidualizacją remitenta ${ }^{50}$.

Po czwarte, podobne opinie, choć w mniejszości, można też spotkać w literaturze $^{51}$. Marcin Czepelak pisze, że „orzecznictwo wymaga tu podania pełnej firmy, włącznie z oznaczeniem rodzaju osoby prawnej wymaganym przez art. $160 \mathrm{KSH}$, i to pod rygorem uznania, że w wekslu nie oznaczono remitenta, co skutkuje nieważ-

\footnotetext{
48 Problem może powstać, gdy będzie kilka podmiotów, które mają ten sam trzon nazwy, ale inną formę prawną. Przykładowo: Legalis sp. z oo. i legalis sp. k.

49 Zob. m.in. art. 1 pkt 1 ustawy z dnia 31 lipca 2019 r. o zmianie niektórych ustaw w celu ograniczenia obciążeń regulacyjnych (Dz. U. poz. 1495), na mocy którego z dniem 1 stycznia 2021 r. został do kodeksu cywilnego dodany nowy art. $385^{5}$, w którym się przewiduje, że instytucję klauzul niedozwolonych stosuje się również do osoby fizycznej zawierającej umowę bezpośrednio związaną z jej działalnością gospodarczą, gdy z treści tej umowy wynika, że nie posiada ona dla niej charakteru zawodowego, wynikającego w szczególności z przedmiotu wykonywanej przez nią działalności gospodarczej, udostępnionego na podstawie przepisów o Centralnej Ewidencji i Informacji o Działalności Gospodarczej.

50 O złożoności tego procesu świadczą liczne uchwały SN dotyczące wykładni weksla. Zob. przykładowo: uchwała SN z dnia 17 kwietnia 2015 r., III CZP 11/15, OSNC 2016, z. 4, poz. 42 i przywołane tam orzeczenia.

51 „Z lektury tego wyroku wynika jasny wniosek dla praktyki, aby posługiwać się pełną firmą remitenta będącego przedsiębiorcą, zawierającą także określenie formy prawnej osoby prawnej (przy tym to ostatnie może być podane w skrócie - por. art. 435 § 2 k.c.)". Zob. J. Jastrzębski, Prawo..., komentarz do art. 1 pkt 15. Należy jednak zaznaczyć, że występują też stanowiska przeciwne. Zob. m.in. Ł. Węgrzynowski, Oznaczenie..., s. 37 i n.; A. Szpunar, Uwagi o wykładni weksla, „Rejent” 1994, nr 2, s. 71; R. Marek, Skutki..., s. 33 i n.
} 
nością" ${ }^{52}$.W piśmiennictwie można też przeczytać, że „niedopuszczalne jest oznaczenie remitenta w sposób pośredni (bez podania nazwiska), choćby jego identyfikacja była możliwa (...). Unieważniają weksel także inne warianty pośredniego oznaczenia remitenta"53. Można się zastanawiać, czy wskazanie jej skrótu zamiast firmy nie stanowi „pośredniego" wskazania remitenta. Jeżeli tak, to również i na tej podstawie można by postawić tezę o nieważności weksla.

Mimo tych argumentów, przyjęcie tezy, że remitent powinien być oznaczony w sposób zgodny ze swoją firmą ujawnioną w rejestrze pod rygorem nieważności weksla, należy uznać za nadmierny formalizm. W przypadkach w których na wekslu występowałby sam skrót, taka teza za pomocą wyżej wspomnianych argumentów może jakoś by się broniła. Rezygnacja z rozróżnienia na oznaczenie i indywidualizację rodziłaby jednak problem w sytuacjach, w których na wekslu obok skrótu podany byłby też np. numer KRS. W takim przypadku upadałby argument o negatywnym wpływie na funkcję obrotową, a pozostałe argumenty wypadałyby zbyt słabo.

Podsumowując, postanowienie I CSK 716/17 należy poddać uzasadnionej krytyce. Teza SN, że remitent powinien być dostatecznie zindywidualizowany, a posługiwanie się nazwami handlowymi upowszechnionymi w obrocie masowym jest dopuszczalne, wydaje się co najmniej nieprawidłowo i niedostatecznie uzasadniona. Po pierwsze, SN na uzasadnienie swojej tezy powołuje się na dwa orzeczenia, z których takie stwierdzenie nie wynika. Po drugie, SN nie zwraca uwagi na istotne rozróżnienie na oznaczenie remitenta i jego indywidualizację. Dopiero wyraźne wprowadzenie takiej dystynkcji sprawia, że postawiona przez SN teza się broni. Jednak problem oznaczenia remitenta za pomocą skrótu firmy (zwłaszcza, że skrót ten obecnie nie jest ujawniany w rejestrze $)^{54}$, wydaje się ważki i szkoda, że SN nie poświęcił mu więcej uwagi. Co prawda, postanowienie nie było orzeczeniem merytorycznym, więc brak pogłębionych rozważań może nie dziwić. Jednak jest to już kolejne z postanowień Sądu Najwyższego, które autor niniejszej glosy poddaje krytyce ${ }^{55}$. Można odnieść wrażenie, że SN, widząc czasem źle napisaną skargę kasacyjną albo bardzo poważne błędy sądów niższych instancji, bagatelizuje problem i nie analizuje go prawidłowo, stawiając przy okazji tezy,

52 M. Czepelak [w:] System Prawa Handlowego, t. 4, Prawo instrumentów finansowych, red. M. Stec, Warszawa 2016, s. 154. Takie sformułowanie sprawia, że nie jest jasne, czy wspomniany autor podziela stanowisko orzecznictwa. Co więcej, na uzasadnienie przytoczonego stwierdzenia M. Czepelak powołuje się na wyrok V CSK 258/11; tym samym mogą powstać wątpliwości, czy rzeczywiście taki jest pogląd judykatury. Zob. jednak też: T. Nowak, Prawo wekslowe i czekowe, Warszawa-Poznań 1992, s. 12-13 oraz M. Czarnecki, L. Bagińska, Prawo wekslowe i czekowe. Komentarz, Warszawa 2013, s. 113, s. 119 i s. 564.

53 Zob. J. Jastrzębski, Prawo..., komentarz do art. 1 pkt 15.

54 Postulat zmiany przepisów u.k.r.s. w tym zakresie zgłaszany w doktrynie jest już od dawna. Zob. P. Zaporowski, Zagadnienie..., s. 586 oraz inny autorzy przywoływani w tej publikacji.

55 Zob. T. Tomczak, Jurysdykcja oraz prawo właściwe dla dziedziczenia testamentowego praw rzeczowych w świetle rozporzq̨dzenia nr 650/2012, „Transformacje Prawa Prywatnego” 2019, nr 4, s. 53-80. W artykule tym skrytykowane zostało postawienie SN z dnia 11 marca 2016 r., I CSK 64/15, Legalis nr 1446209. Glosę krytyczną do tego postanowienia napisał również P. Czubik: idem, Krytyczna analiza postanowienia Sądu Najwyższego z dnia 11 marca 2016 r., I CSK 64/15, „Problemy Współczesnego Prawa Międzynarodowego, Europejskiego i Porównawczego" 2017, nr 15, s. 168-175. 
które później rodzą więcej problemów niż rozwiązują. Wydaje się, że należałoby rozważyć, czy w sytuacjach, w których SN nie orzeka merytorycznie, nie powinien również wstrzymywać się od stawiania na marginesie merytorycznych tez.

\section{Literatura}

Adamus R., Dopuszczalność skracania korpusu spółki kapitałowej, „Prawo Spółek” 2012, nr 9.

Adamus R., W sprawie dopuszczalności skracania korpusu spółki kapitałowej, ,Rejent” 2012, nr 6.

Bendza W., Podpis wystawcy weksla będq̨cego osobą prawną. Glosa do uchwały SN z 10.10.2013 r., III CZP 54/13, PiP 2016, z. 1.

Czarnecki M., Bagińska L., Prawo wekslowe i czekowe. Komentarz, Warszawa 2013.

Czepelak M. [w:] System Prawa Handlowego, t. 4, Prawo instrumentów finansowych, red. M. Stec, Warszawa 2016.

Czubik P., Krytyczna analiza postanowienia Sądu Najwyższego z dnia 11 marca 2016 r., I CSK 64/15, „Problemy Współczesnego Prawa Międzynarodowego, Europejskiego i Porównawczego" 2017, nr 15.

Dziadzio M., Ochwat P., Dopuszczalność skracania korpusu firmy spółki kapitałowej w świetle przepisów kodeksu cywilnego, kodeksu spółek handlowych oraz ustawy o krajowym rejestrze sądowym, „Acta Scientifica Academiae Ostroviensis, sectio A, Nauki Humanistyczne, Społeczne i Techniczne" 2016, nr 8.

Gniewek E. [w:] Kodeks cywilny. Komentarz, red. idem, P. Machnikowski, Warszawa 2013.

Górski A., Prawo wekslowe i czekowe, Warszawa 1925.

Jastrzębski J., Kaliński M., Prawo wekslowe i czekowe. Komentarz, Warszawa 2014.

Marek R., Skutki braku pełnej firmy spółki kapitałowej na wekslu, "Monitor Prawa Handlowego" 2015, nr 4.

Nowak T., Prawo wekslowe i czekowe, Warszawa-Poznań 1992.

Popardowski P. [w:] Ustawa o Krajowym Rejestrze Saqdowym. Komentarz, red. K. Osajda, Warszawa 2020.

Rosenblüth I., Prawo wekslowe i czekowe. Komentarz, t. 1, Kraków 1936.

Stefanicki R., Prawo do nazwy (firmy) i jego ochrona, „Prawo Spółek” 1999, nr 2.

Koziński M., Dybiński J. [w:] System Prawa Prywatnego, t. 18, Prawo papierów wartościowych, red. A. Szumański, Warszawa 2016.

Szpunar A., Komentarz do prawa wekslowego i czekowego, Warszawa 2001.

Szpunar A., Uwagi o wykładni weksla, „Rejent" 1994, nr 2.

Szpunar A., Kaliński M., Komentarz do prawa wekslowego i czekowego, Warszawa 2003.

Tarska M. [w:] Komentarz do art. 1-60 ustawy o Krajowym Rejestrze Sądowym. Kodeks spółek handlowych. Pozakodeksowe prawo handlowe. Komentarz, t. 5, red. S. Sołtysiński, A. Szajkowski, A. Szumański, J. Szwaja, Warszawa 2015.

Tomczak T., Jurysdykcja oraz prawo właściwe dla dziedziczenia testamentowego praw rzeczowych w świetle rozporządzenia nr 650/2012, „Transformacje Prawa Prywatnego” 2019, nr 4.

Węgrzynowski Ł., Oznaczenie spółki kapitałowej na wekslu , Przegląd Sądowy" 2017, nr 6.

Wróblewski S., Prawo wekslowe i czekowe, Kraków 1936.

Wrzołek-Romańczuk M., "Wpis niedopuszczalny” w Krajowym Rejestrze Sądowym, "Przegląd Prawa Handlowego" 2002, nr 4. 
Zaporowski P., Zagadnienie rejestracji skrótu firmy [w:] Księga dla naszych Kolegów. Prace prawnicze poświęcone pamięci doktora Andrzeja Ciska, doktora Zygmunta Masternaka, doktora Marka Zagrosika, red. J. Mazurkiewicz, Wrocław 2013.

Zaporowski P., Zalety i wady unormowania skracania firm w art. 43(5) § 4 k.C., ,Kwartalnik Prawa Prywatnego" 2006, nr 4.

\section{Streszczenie}

\section{Tomasz Tomczak}

\section{Oznaczenie i indywidualizacja remitenta}

Przedmiotem glosy do postanowienia Sądu Najwyższego z dnia 9 kwietnia 2018 r., I CSK 716/17, jest stanowisko sądu dotyczące indywidualizacji remitenta. Sama teza SN została w glosie zaakceptowana, jednak krytyce zostało poddane jej uzasadnienie.

Słowa kluczowe: weksel; weksel własny; remitent; oznaczenie remitenta; indywidualizacja remitenta.

\section{Summary}

\section{Tomasz Tomczak}

\section{Remitter's Specification and Individualization}

The commentary to the judgment of the Supreme Court of 9 April 2018, case reference number ICSK $716 / 17$, is devoted to the position of the Court regarding the individualization of a remitter. The thesis of the Supreme Court has been approved by the Author, however, the justification of the thesis has been criticized.

Keywords: bill of exchange; promissory note; remitter; remitter's specification; remitter's individualization. 